\title{
PENGEMBANGAN METODE IDENTIFIKASI DAN PENETAPAN KADAR RODAMIN B PADA SAMPEL JAJANAN TRADISIONAL DENGAN METODE KROMATOGRAFI LAPIS TIPIS- SPEKTROFOTODENSITOMETRI
}

\author{
Pande Made Nova Armita Sari ${ }^{1}$, Ni Made Widi Astuti ${ }^{2}$, Ni Kadek Warditiani ${ }^{3}$, \\ I Made Agus Gelgel Wirasuta ${ }^{4}$ \\ 1,2,3 Program Studi Farmasi, Fakultas Matematika dan Ilmu Pengetahuan Alam, \\ Universitas Udayana. Kampus Bukit Jimbaran, Bali, Indonesia 80361 \\ ${ }^{1,4}$ UPT. Laboratorium Forensik Sains dan Kriminologi Universitas Udayana. \\ Kampus Bukit Jimbaran, Bali, Indonesia 80361 \\ E-mail: nova.armita@unud.ac.id
}

\begin{abstract}
ABSTRAK
Zat pewarna sintetis digunakan karena komposisinya lebih stabil dan relatif lebih murah. Contoh pewarna sintetis adalah sunset yellow FCF yang memberi warna oranye, karmoisin yang memberikan warna merah, serta Tartrazine untuk warna kuning. Zat warna yang dilarang digunakan dalam pangan tercantum dalam Peraturan Menteri Kesehatan RI Nomor 239/MenKes/Per/V/85 mengenai Zat Warna Tertentu yang Dinyatakan sebagai Bahan Berbahaya. Salah satu zat warna yang dinyatakan bahan berbahaya adalah rodamin B. Rodamin B masih banyak ditemukan pada produk kosmetik dan juga berbagai komoditas pangan. Paparan jangka panjang dengan rodamin B dapat menyebabkan kanker dan resiko cacat kelahiran. Oleh karena itu akan dikembangkan metode analisis kromatografi lapis tipis (KLT) untuk identifikasi dan penetapan kadar rodamin B di produk jajanan tradisional. Dikembangkan enam fase gerak untuk memisahkan senyawa rodamin B dari pewarna lain. Dari hasil yang diperoleh,fase gerak 6 (Etanol:air:asam asetat:dietilamin (95:5:5:1) adalah fase gerak yang paling mampu memisahkan beberapa pewarna sekaligus. Uji kualitatif dengan KLT-spektrofotodensitometri didapatkan bahwa sampel yang positif mengandung rodamin B adalah sampel KM3 dan KM 5. Hal ini disimpulkan dari Rf dan spektrum yang sama dengan rodamin, yaitu $\mathrm{Rf} 0,72$. Persamaan garis regresi yang diperoleh adalah $\mathrm{y}=564,534+1,799 \mathrm{x}$ dan $\mathrm{r}$ $=0,9946$ dengan rentang linieritas 200-1500 ppm. Pada penetapan kadar sampel yang mengandung rodamin B, yaitu pada sampel KM3 dan KM B, secara berturut-turut kadar yang diperoleh adalah $0,676 \mathrm{mg} / 1$ gram sampel dan $2,751 \mathrm{mg} / 1$ gram sampel
\end{abstract}

Kata kunci: metode, rodamin B, KLT, jajanan, spektrofotodensitometri

\begin{abstract}
Synthetic dyes are used because they are more stable in final product and relatively affordable. Some examples of synthetic dyes are sunset yellow FCF which gives an orange color, carmoisin which gives a red color, and Tartrazine for yellow hue. Dyes those are prohibited from being used in food are listed in the Regulation of the Ministry of Health of the Republic of Indonesia Number 239/MenKes/Per/V/85 concerning Certain Dyes Declared as Hazardous Materials. One of the dye declared as a hazardous material is rhodamine B. Rodamin B is still found in many cosmetic products and also in various food commodities. Long-term exposure to rhodamine B can lead to cancer and a risk of birth defects. Therefore a thin layer chromatography (TLC) analysis method has been developed for the identification and determination of rhodamine B content in traditional snack products. Six mobile phases were developed to separate rhodamine B compounds from other dyes. From the results obtained, the mobile phase 6 (Ethanol: water: acetic acid: diethylamine (95: 5: 5: 1 ) is the mobile phase which is most capable of separating several dyes at once. Qualitative analysis using thin layer chromatography-spectrophotodensitometry showed that the presence of rodhamine B was found in KM3 and KM5 sample. This was concluded from the Rf and spectrum of the sample 99

Pande Made Nova Armita Sari, Ni Made Widi Astuti, Ni Kadek Warditiani, I Made Agus Gelgel Wirasuta Program Studi Farmasi, Fakultas Matematika dan Ilmu Pengetahuan Alam, Universitas Udayana. Kampus Bukit Jimbaran, Bali, Indonesia 80361 UPT. Laboratorium Forensik Sains dan Kriminologi Universitas Udayana. Kampus Bukit Jimbaran, Bali, Indonesia 80361
\end{abstract}


peak which was similar to the rhodamine B reference. The Rf was 0.72.The regression linier of rhodamine $B$ was $y=564.534+1.799 x$ and $r=0.9946$ with a linearity range of $200-1500 \mathrm{ppm}$. The determination of rodhamine B in the samples, namely the KM3 and KM B were $0.676 \mathrm{mg} / 1 \mathrm{gram}$ sample and $2.751 \mathrm{mg} / 1$ gram sample, respectively.

Keywords: method, rhodamine B, TLC, traditional snack, spectrophotodensitometry

\section{PENDAHULUAN}

Pewarna adalah salah satu jenis bahan tambahan pangan (BTP) yang ditambahkan pada produk makanan untuk menambah nilai estetika dari makanan tersebut. Pewarna ditambahkan agar makanan terlihat menarik sehingga dapat meningkatkan keinginan konsumen untuk membeli produk tersebut. Zat pewarna yang sering digunakan dalam produksi pangan adalah zat pewarna alami ataupun sintetis. Zat pewarna alami berasal dari warna alami (pigmen) yang terkandung dalam tanaman, misalnya klorofil akan menghasilkan warna hijau, warna oranye berasal dari karotenoid wortel, serta warna merah dari umbi bit. Sementara itu zat pewarna sintetis merupakan zat pewarna yang dibuat dengan sengaja melalui pengolahan industri. Zat pewarna sintetis digunakan karena komposisinya lebih stabil dan relatif lebih murah. Contoh pewarna sintetis adalah sunset yellow FCF yang memberi warna oranye, karmoisin yang memberikan warna merah, serta Tartrazine untuk warna kuning.

Penggunaan pewarna alami dan sintetis ini diatur dalam Peraturan Menteri Kesehatan RI Nomor 722/MenKes/Per/VI/88 mengenai Bahan Tambahan Makanan. Pengawasan penggunaan pewarna sintetis dilakukan oleh Balai Besar
Pengawasan Obat dan Makanan Republik Indonesia agar dapat dilakukan kontrol terhadap penggunaan zat pewarna yang konsentrasinya berlebihan, tidak tepat, dan terutama penggunaan zat pewarna berbahaya yang tidak diperuntukkan untuk pangan karena dapat memberikan dampak negatif terhadap kesehatan. Zat warna yang dilarang digunakan dalam pangan tercantum dalam Peraturan Menteri Kesehatan RI Nomor 239/MenKes/Per/V/85 mengenai Zat Warna Tertentu yang Dinyatakan sebagai Bahan Berbahaya [1,2]. Berdasarkan peraturan dari Kementerian Kesehatan Republik Indonesia (Kemenkes RI) dan Badan Pengawas Obat dan Makanan (BPOM), salah satu zat warna yang dinyatakan bahan berbahaya adalah rodamin B. Rodamin B masih banyak ditemukan pada produk kosmetik dan juga berbagai komoditas pangan.

Berdasarkan data pengawasan jajanan pasar di Provinsi Bali pada tahun 2018 oleh Balai Besar Pengawasan Obat dan Makanan di Denpasar, terhadap tiga Kabupaten yang berbeda di Bali, ditemukan bahwa masih ada jajanan pasar tradisional yang positif mengandung pewarna rodamin B. BPOM telah melakukan berbagai upaya dalam membebaskan komoditas pangan dari pewarna sintetis berbahaya rodamin 
B. BBPOM di Denpasar telah melakukan berbagai macam penyuluhan mengenai Keamanan Pangan serta Pengawasan dan tentang Cara Pembuatan Pangan Olahan yang Baik (CPPOB) $[3,4]$.

Rodamin B jika terkena cahaya matahari, maka dapat membentuk senyawa oksigen reaktif, Reaksi ini dapat meningkatkan energi dari rodamin B sehingga senyawa ini dapat memasuki biomolekul untuk membentuk senyawa oksigen reaktif. Saat rodamin B memasuki tubuh kita bersamaan dengan makanan, maka dapat memicu stress oksidatif pada folikel ovari [5]. Paparan jangka panjang dengan rodamin $\mathrm{B}$ dapat menyebabkan kanker dan resiko cacat kelahiran [6-8]. Rodamin B dapat menyebabkan iritasi kulit dan saluran pernafasan, serta bersifat karsinogenik dan mutagenik [9]. Untuk itu diperlukan suatu metode analisis rodamin B dalam produk pangan guna mendapatkan suatu metode analisis yang efisien, sensitif dan cepat. Metode analisis Rodamin B pada kosmetik telah dilakukan dengan metode HPLC (High Performance Liquid Chromatography) [10]. Selain itu analisis rodamin B pada produk pangan juga telah dilakukan dengan HPLC [11]. Metode HPLC merupakan metode analisis yang selektif, namun metode ini membutuhkan investasi yang mahal. Oleh karena itu akan dikembangkan metode analisis kromatografi lapis tipis (KLT) untuk identifikasi dan penetapan kadar rodamin B di produk jajanan tradisional. Metode KLT sudah berulang kali dipergunakan untuk mengidentifikasi dan juga menetapkan kadar senyawa rhodamine B pada berbagai produk makanan ataupun kosmetik. Namun kebanyakan dari sistem KLT yang dipergunakan memiliki $\mathrm{Rf}$ yang berada di front line pelarut ataupun masih menghasilkan puncak yang berekor (tailing). Nilai Rf yang ideal adalah Rf antara 0,2-0,8. Selain itu system KLT yang dikembangkan diharapkan akan mampu memisahkan berbagai pewarna merah jenis lain yang terdapat dalam produk makanan.

\section{METODE PENELITIAN Bahan dan Peralatan}

Bahan yang digunakan adalah etanol p.a (Merck), etanol 70\% (Brataco), asam asetat p.a (Merck), etil asetat p.a (Merck), n-butanol p.a (Merck), aquades (Brataco), $\mathrm{HCl}$ p.a (Merck), amonia p.a (Merck).

Alat yang digunakan adalah alat gelas (Pyrex), plat kromatografi lapis tipis Silica Gel F254 (Merck), chamber (CAMAG), Automatic TLC Sampler (CAMAG), TLC Visualizer (CAMAG) dan TLC Scanner (CAMAG).

\section{Metode}

A. Preparasi sampel

Ditimbang masing-masing $1 \mathrm{~g}$ sampel jajanan pasar yang memiliki warna merah yang mencolok, kemudian ditempatkan dalam gelas Erlenmeyer, ditambahkan $10 \mathrm{~mL}$ amonia $2 \%$ dalam etanol $70 \%$. Sampel direndam selama 24 jam. Sampel disaring dengan kertas saring whatman no. 1, kemudian diuapkan. 
Residu dilarutkan dengan $10 \mathrm{~mL}$ larutan yang dibuat dari campuran air dan asam asetat $10 \%(2: 1)$. Untuk menjerap zat warna, ditambahkan benang wol dan dididihkan selama 15 menit. Zat warna yang terjerap ke dalam benang wol kemudian dilarutkan dengan $10 \mathrm{~mL}$ amonia $10 \%$ dalam etanol $10 \%$. Zat warna dalam larutan basa ini kemudian akan dianalisis dengan KLT.

B. Preparasi larutan stok dan seri Larutan stok dan seri rodamin B dibuat dengan konsentrasi sebesar 200 ppm. Larutan seri dibuat dengan melakukan pemipetan pada larutan baku dengan konsentrasi larutan seri sebesar 50; 75; 100; 125; 150 ppm.
Pelarut yang digunakan pada pembuatan larutan stok dan seri adalah larutan $\mathrm{HCl} 0,1 \mathrm{~N}$.

C. Kromatografi Lapis Tipis

Plat kromatografi lapis tipis Silica Gel F254 dicuci dan diaktivasi sebelum digunakan. Sampel ditotolkan pada plat KLT menggunakan Automatic TLC Sampler 4 (ATS). Proses elusi dilakukan dengan berbagai komposisi fase gerak. Plat KLT yang telah ditotol, dimasukkan ke dalam Chamber yang sudah berisi fase gerak yang telah dijenuhkan. Di bawah berikut adalah beberapa komposisi fase gerak yang digunakan dalam optimasi pemisahan rodamin $\mathrm{B}$ dengan KLT.

Tabel 1. Fase Gerak yang Dioptimasi

\begin{tabular}{cll}
\hline No & \multicolumn{1}{c}{ Fase Gerak } & \multicolumn{1}{c}{ Komposisi Fase Gerak } \\
\hline 1 & Fase Gerak 1 & Isopropanol: Amonia (6:1) \\
\hline 2 & Fase Gerak 2 & Etanol 70\%: ammonia (19:1) \\
\hline 3 & Fase Gerak 3 & Isopropanol:amonia (4:1) \\
\hline 4 & Fase Gerak 4 & n-butanol:etilasetat:amonia $(10: 4: 5)$ \\
\hline 5 & Fase Gerak 5 & Etil asetat: metanol:amonia $(15: 3: 3)$ \\
\hline 6 & Fase Gerak 6 & Etanol:air:asam asetat:dietilamin (95:5:5:1) \\
\hline
\end{tabular}

Identifikasi dilakukan dengan mengamati warna bercak secara visual serta di bawah sinar UV dengan TLC Visualizer. Pada cahaya putih bercak yang positif mengandung rodamin $\mathrm{B}$ akan memberikan warna merah muda, dan di bawah sinar UV $254 \mathrm{~nm}$ dan 366 $\mathrm{nm}$ berfluoresensi kuning atau orange. Analisis secara spektrofotodensitometri dilakukan dengan TLC Scanner 4 untuk memperoleh kromatogram, spektrum dan juga AUC masing-masing bercak.

\section{HASIL dan PEMBAHASAN}

Pemisahan dan identifikasi senyawa rodamin dilakukan dengan metode kromatografi lapis tipis dengan optimasi berbagai campuran fase gerak. Adapun fase gerak yang dioptimasi ada enam fase gerak dengan komposisi yang berbedabeda. Masing-masing campuran fase gerak memiliki indeks polaritas yang 
berbeda-beda, sehingga pola fase gerak yang dikembangkan yaitu pemisahan yang dihasilkan juga bersifat basa dan campuran fase gerak berbeda yang ditandai dengan nilai $\mathrm{Rf}$ tersebut cenderung polar sampai semi rodamin B yang berbeda pada tiap polar. Dengan fase gerak yang dibuat fase gerak. Adapun urutan indeks polaritas dari keenam fase gerak dari yang paling polar adalah fase gerak 6 $(5,4)$; fase gerak $5(4,1)$; fase gerak 2 $(4,9)$; fase gerak $1(3,3)$; fase gerak 3 $(3,1)$ dan fase gerak $4(3,0)$. Namun dalam suasana basa ini, maka senyawa rodamin $\mathrm{B}$ akan berada dalam bentuk garamnya, dan mudah larut dalam pembawa polar sampai semi polar.

Tabel 2. Pemisahan Standard dan Sampel dengan Berbagai Fase Gerak

Fase Gerak 1




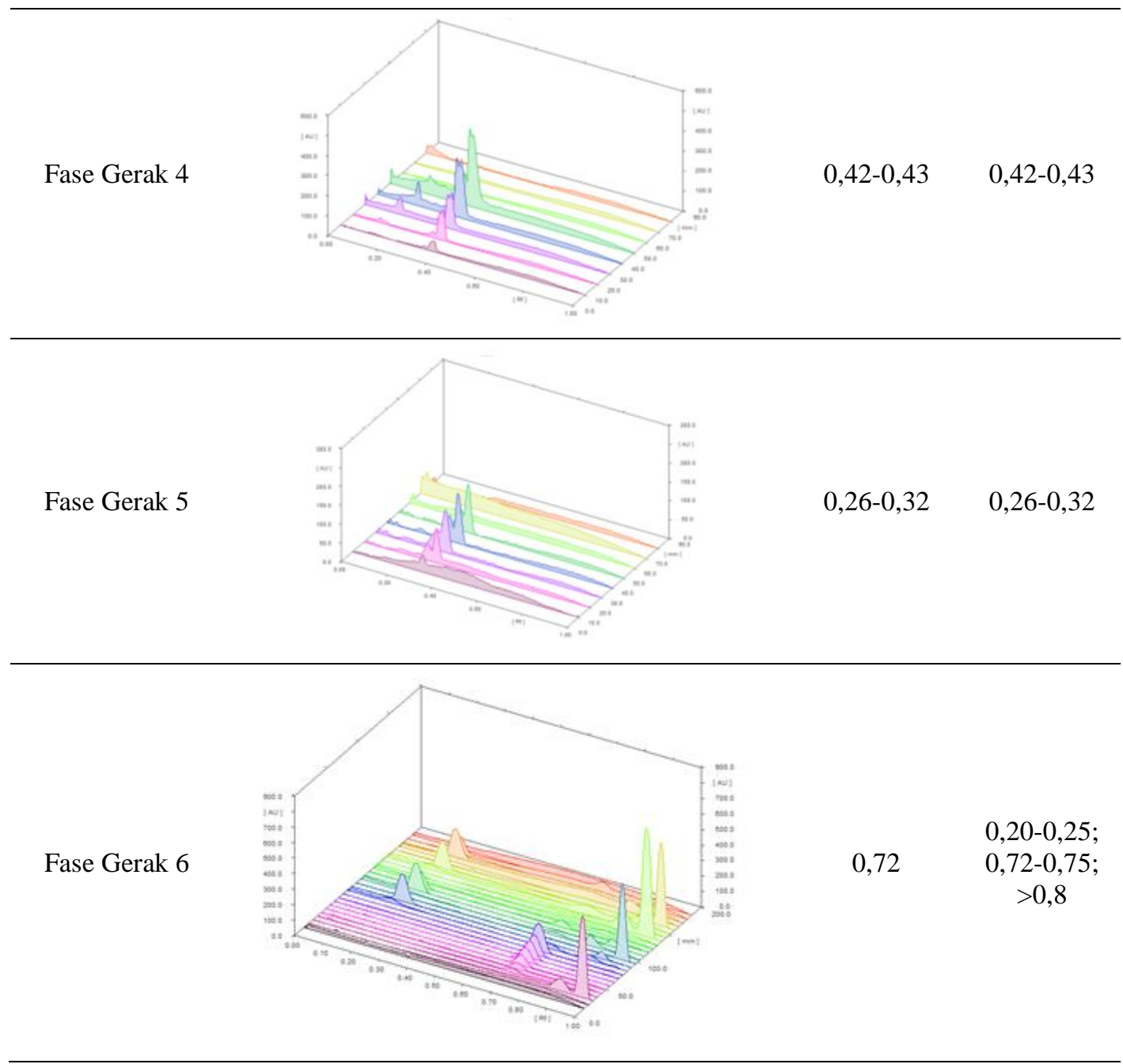

Fase gerak 1 memberikan puncak standar dan sampel yang tailing atau melebar. Sementara itu pada fase gerak 2 puncak muncul pada front line plat KLT, yaitu pada $\mathrm{Rf}>0,8$. Pada fase gerak 6, muncul paling banyak puncak, yaitu pada Rf 0,20 0,$25 ; \quad 0,72-0,75 ; \quad>0,8$. Standar rodamin B memiliki Rf 0,72. Puncak lain yang muncul pada $\operatorname{Rf} 0,20$ 0,25dan > 0,8 diperkirakan sebagai jenis pewarna lain. Ini menunjukkan bahwa fase gerak 6 adalah fase gerak yang cukup baik karena dapat memisahkan beberapa pewarna yang berbeda. Fase gerak 3 dan 5 menunjukkan pemisahan sampel dengan Rf antara 0,4-0,45 dan 0,260,32 dengan masih menunjukkan puncak-puncak yang tailing atau belum terpisah dengan baik. Fase gerak 4 menghasilkan pemisahan pewarna dengan rentang $\operatorname{Rf} 0,42$ 0,45 . Pada fase gerak 4 dan 5 puncakpuncak yang muncul masih berada dekat dengan titik penotolan, yang mana ini berarti bahwa kedua fase gerak tersebut belum mampu membawa senyawa analit (pewarna ) bergerak sepanjang jalur pemisahan 104

Pande Made Nova Armita Sari, Ni Made Widi Astuti, 
sehingga pemisahan yang dihasilkan masih kurang optimal. Dari keenam fase gerak yang digunakan, fase gerak 6 adalah fase gerak yang telah mampu memisahkan beberapa jenis pewarna dengan jarak pisah yang cukup jauh dari titik penotolan, dimana rentang Rf yang dihasilkan dari tiga jenis pewarna yang berhasil terpisah adalah masih memenuhi ketentuan 0,2-0,8. Puncak yang dihasilkanpun tidak mengalami tailing. Dari keenam fase gerak, fase gerak 6 adalah fase gerak yang paling mampu untuk memisahkan beberapa jenis pewarna merah yang ada pada berbagai sampel. Fase gerak 6 mengandung pelarut dietilamin sebagai pemberi sifat basanya, sementara itu pada fase gerak yang lain menggunakan amonia. Amonia sangat mudah menguap sehingga, sifat kebasaan fase gerak dapat berubah dengan cepat. Namun pada fase gerak 6 digunakan dietilamin yang relative lebih less volatile dibandingkan dengan ammonia sehingga sifat kebasaan fase gerak lebih dapat dipertahankan. Hal ini sangat berperan terhadap daya pisah fase gerak terhadap senyawa rodamin B. Pada visualisasi dengan sinar ultraviolet $366 \mathrm{~nm}$, pada track senyawa standar rodamin B dan sampel KM3 dan KM5 terdapat puncak dengan warna pendaran berwarna kuning.

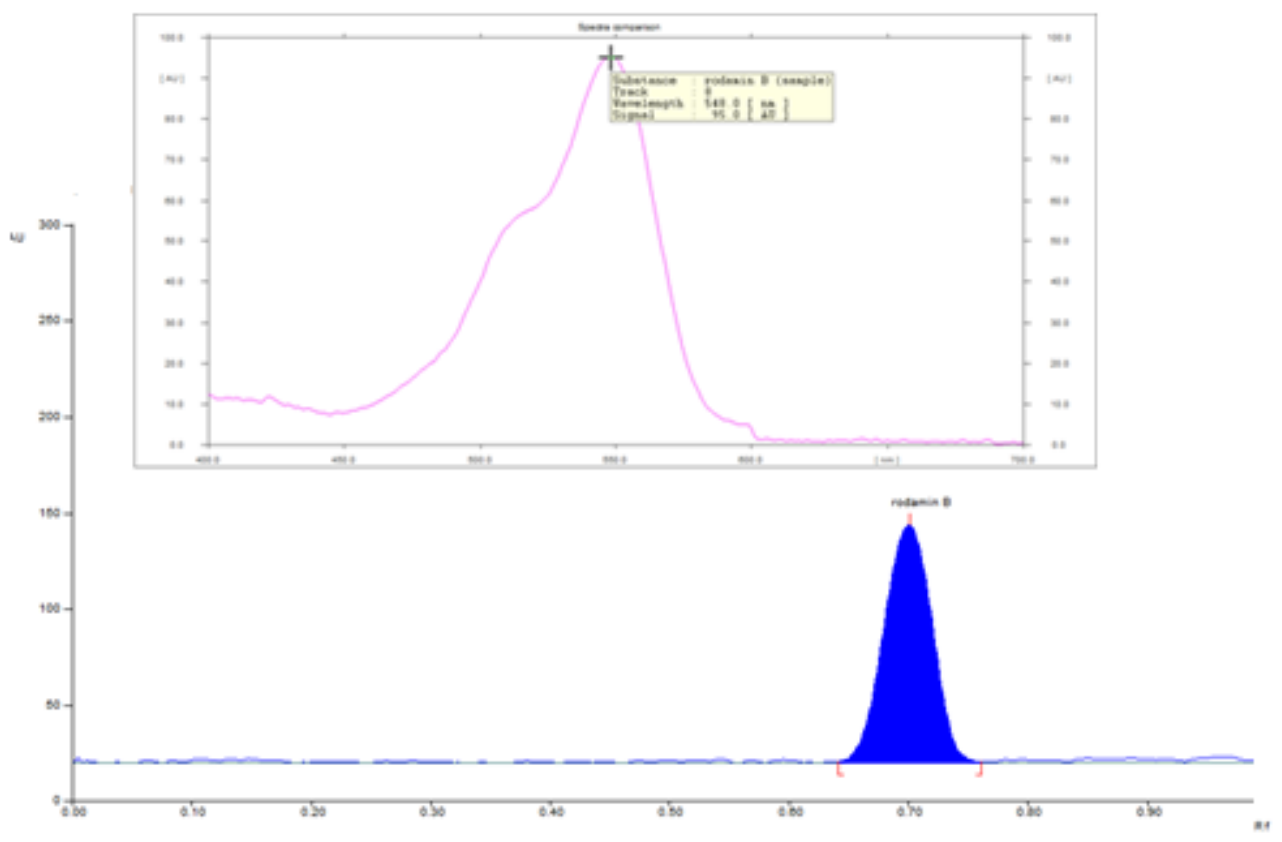

Gambar 1. Puncak dan spektrum senyawa rodamin B pada fase gerak 6

Gambar 1 di atas menunjukkan puncak senyawa standar rodamin B dengan fase gerak etanol:air:asam asetat:dietilamin (95:5:5:1). Puncak yang muncul tidak menunjukkan terjadinya tailing. Panjang 
gelombang maksimum senyawa standar yang dihasilkan adalah 558 $\mathrm{nm}$, yang mana merupakan daerah panjang gelombang sinar tampak. Sampel yang memiliki puncak

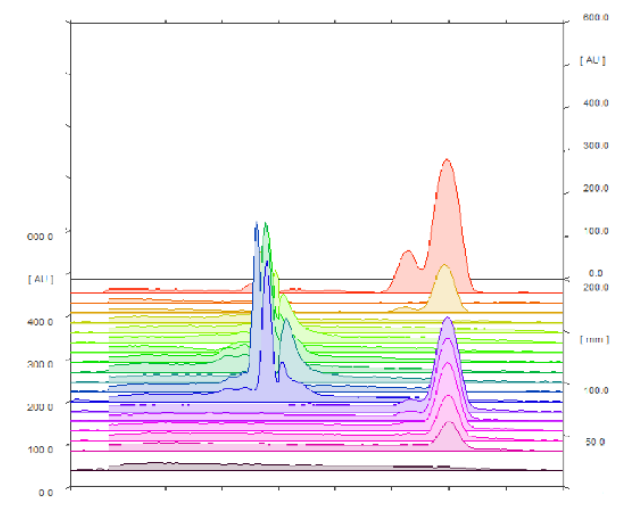

Gambar 2. Puncak dan spektrum senyawa standar rodamin B dan sampel

Sementara itu puncak yang ditemukan pada Rf yang berbeda dengan $\mathrm{Rf}$ senyawa standar rodamin

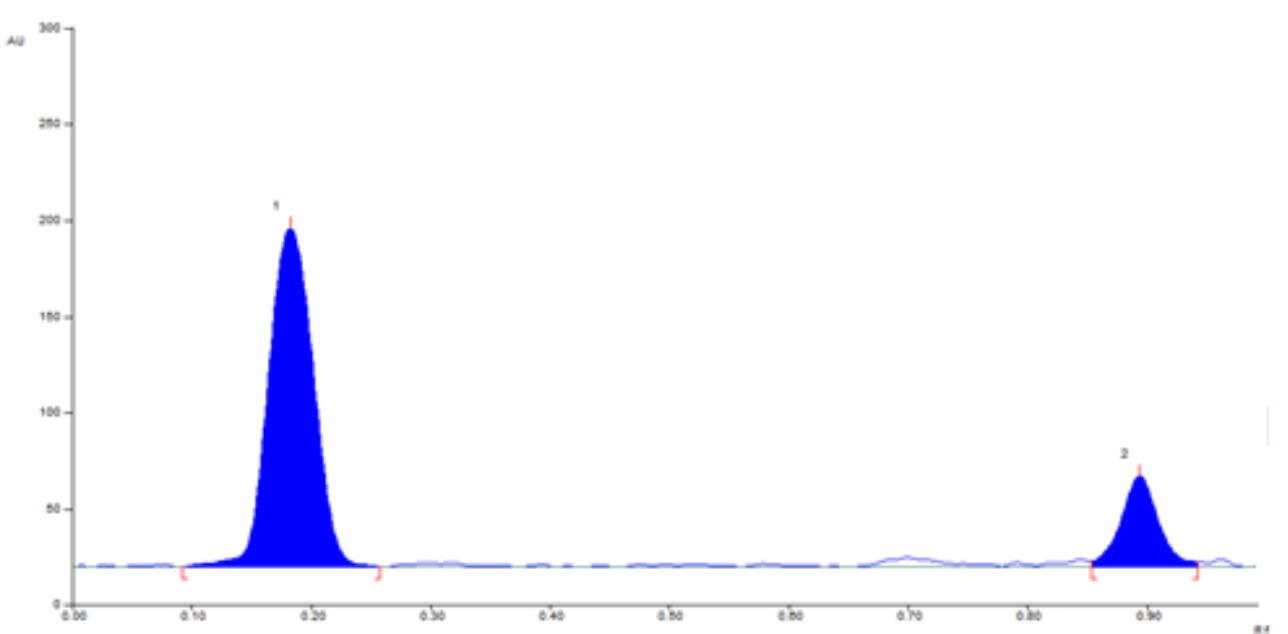

Gambar 3. Gambar puncak yang muncul pada Rf 0,2

Uji linieritas dilakukan untuk melihat hubungan antara konsentrasi analit dengan responnya apakah menunjukkan hubungan yang linier. Ini ditandai dengan koefisien korelasi (r). Berdasarkan perhitungan, dengan nilai Rf dan spektrum yang sama dengan senyawa standar ditemukan pada sampel KM3 dan KM5, seperti yang diperlihatkan pada gambar 2 di bawah berikut.

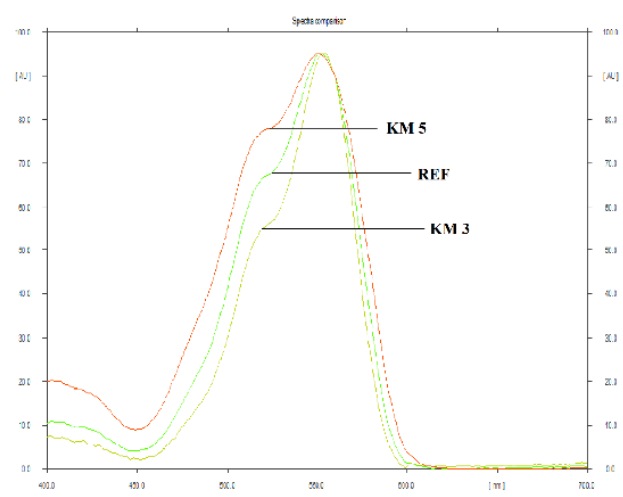

B diperkirakan sebagai jenis pewarna lain seperti terlihat pada gambar 3 di bawah berikut. 


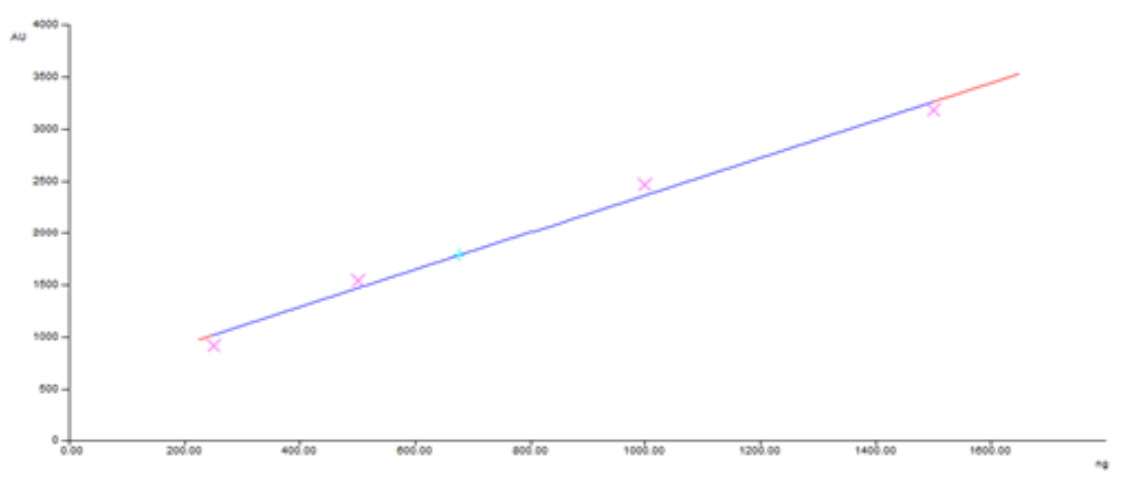

Gambar 4. Persamaan garis regresi linier senyawa rodamin B

Rentang konsentrasi yang masih memberikan respon yang linier adalah 200-1500 ppm. Rentang

konsentrasi di atas 1500 ppm akan membentuk kurva polinomial.

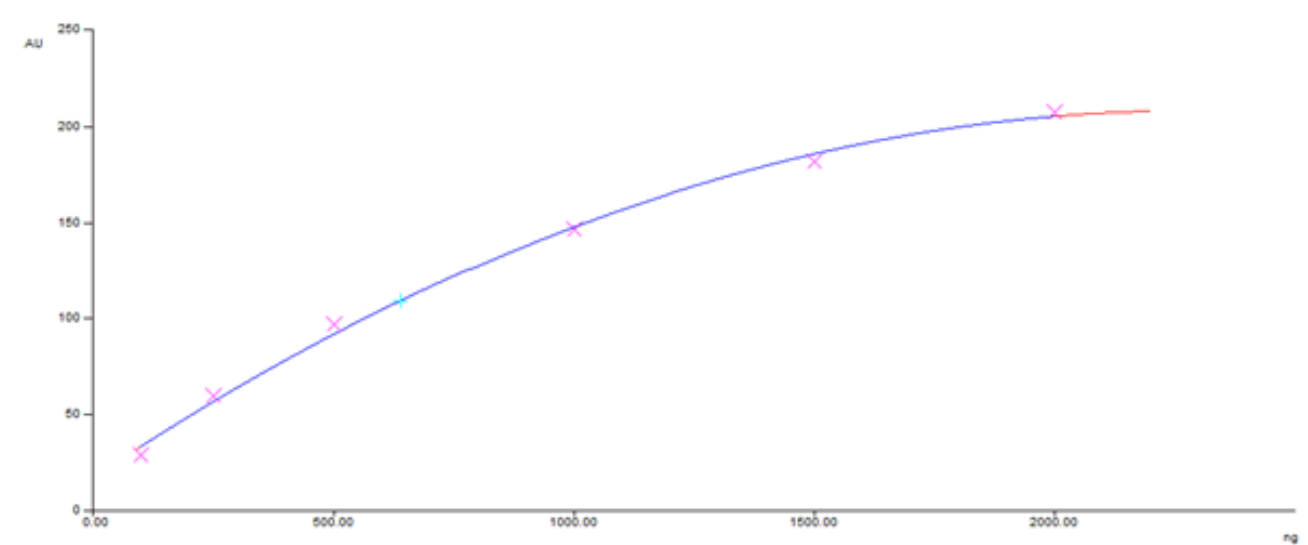

Gambar 5. Persamaan polynomial senyawa rodamin B

Pada penetapan kadar sampel yang mengandung rodamin $\mathrm{B}$, yaitu pada sampel KM3 dan KM5, secara berturut-turut kadar yang diperoleh adalah $0,676 \mathrm{mg} / 1$ gram sampel dan 2,751 mg/1 gram sampel. Pada kedua sampel, Sampel KM 5 melebihi rentang lineritas, sehingga untuk kadarnya digunaan perhitungan berdasarkan persamaan polynomial

\section{DAFTAR PUSTAKA}

[1] Peraturan Menteri Kesehatan RI 722/MenKes/Per/VI/88 
mengenai Bahan Tambahan

Makanan.

[2] Peraturan Menteri Kesehatan RI Nomor

239/MenKes/Per/V/85

mengenai Zat Warna Tertentu yang Dinyatakan Sebagai Bahan Berbahaya.

[3] BPOM RI. 2018. BPOM Amankan terus Pangan di Pasar Tradisional di Bali.https://www.pom.go.id/ne w/view/more/berita/14935/BP OM-Amankan-terus-Pangandi-4.html

[4] BPOM RI. 2017. Informasi Penting Bagi Pelaku Usaha bebaskan Rodamin B. https://www.pom.go.id/new/vi ew/more/berita/13552/Informa si-Penting-Bagi-Pelaku-Usahabebaskan-Rodamin-B.html

[5] Yeni Agus Safitri a, I. Wayan Agung Indrawanb, Sri Winarsih. 2015. Rhodamine B induces oxidative stress and cervical epithelial cell proliferation in the uterus. http://dx.doi.org/10.1016/j.toxr ep.2015.08.013. Toxicology Reports 2 (2015) 1434-1436.

[6] International Agency for Research on Cancer (IARC); IARC Monographs on the Evaluation of Carcinogenic Risk of Chemicals to Man, Volume 16. Some Aromatic Amines and Related Nitro Compounds; World Health Organization: Lyon, France, 1978.

[7] Harris, N.L.; Jaffe, E.S.; Diebold, J.; Flandrin, G.; Muller-Hermelink, H.K.;
Vardiman, J.; Lister, T.A.; Bloomfield, C.D. The World Health Organization Classification of Neoplastic Diseases of the Hematopoietic and Lymphoid Tissues: Report of the Clinical Advisory Committee Meeting, Airlie House, Virginia, November, 1997. Ann. Oncol. 1999, 10, 1419-1432.

[8] Chen, Y.M.; Yu, M. Rhodamine B Staining Foods on the Human Body and Test. Friend of Science Amateurs 2011, 9, 153-157.

[9] Badan Pengawas Obat dan Makanan Republik Indonesia. Keputusan Direktur Jenderal Pengawasan Obat dan Makanan Republik Indonesia Nomor : 00386/C/SK/II/90 Tentang Perubahan Lampiran Peraturan Menteri Kesehatan Nomor : 239/Menkes/Per/V/85 Tentang Zat Warna Tertentu yang Dinyatakan Sebagai Bahan Berbahaya. Jakarta: Direktorat Jenderal Pengawasan Obat dan Makanan; 1990.

[10] Rapid and Sensitive Determination of Rhodamine B in Cosmetics. 2016. Huang Xiongfeng, Xu Qun, Jeffrey Rohrer. Thermo Fisher Scientific, Shanghai and Sunnyvale.

[11] Optimization and Validation of HPLC for the Analysis of Rhodamine-B in Sponge Cake. 2015. Novi Yantiha, Zuhelmi Aziza, Aditya Dicky Prasetya. Proceedings of The 9 th Joint Conference on Chemistry 